\title{
Prevalence of ectoparasites of the barn swallow (Hirundo rustica) in the town of Dschang, West Region, Cameroon
}

\author{
D.B. Kenko Nkontcheu, N. Ngameni Tchamadeu \\ Laboratory for Biology and Applied Ecology (LABEA), Department of Animal Biology, University \\ of Dschang, Cameroon
}

\begin{abstract}
To estimate the prevalence of ectoparasites of the barn swallow $(H$. rustica) in Dschang and to see if this bird can be a risk to public health, an investigation was carried out in three sites. An analysis of 51 swallows showed that $35.29 \%$ of these birds carry at least one species of ectoparasite. Four species were identified, with the following prevalence: $31.37 \%$ (Eomenacanthus stramineus), $5.88 \%$ (Goniocotes gallinae), $3.92 \%$ (Menacanthus cornutus) and $3.92 \%$ (Menopon gallinae). The only significant difference in prevalence between sites was observed with $E$. stramineus and $G$. gallinae. Sex did not influence the prevalence of ectoparasites. Swallows of low weight were the most infested. The diversity of nest building material is an indicator of the exploration of several types of media for nest building. Diversity and equitability indexes were 1.05 and 0.53 , respectively. A survey carried out using questionnaires showed that swallows are consumed by $30 \%$ of the respondents and are used in traditional medicines. These interactions can pose risks to the human population, although we did not find any zoonotic species.
\end{abstract}

\section{Introduction}

Birds are the freest animals in their movements and their ability to fly makes them one of the most mobile animals, some species being migra-

Correspondence: Daniel B. Kenko Nkontcheu, Laboratory for Biology and Applied Ecology (LABEA), Department of Animal Biology, Faculty of Science, University of Dschang, P.0. Box 67, Dschang, Cameroon.

Tel.: +237.7542 .1268 .

E-mail: danielkenko@gmail.com

Key words: barn swallows, ectoparasites, prevalence.

Received for publication: 12 February 2013.

Revision received: 15 July 2013.

Accepted for publication: 7 August 2013.

(C) Copyright D.B. Kenko Nkontcheu and N. Ngameni Tchamadeu, 2013 Licensee PAGEPress, Italy

Journal of Entomological and Acarological Research 2013; 45:e24 doi:10.4081/jear.2013.e24

This article is distributed under the terms of the Creative Commons Attribution Noncommercial License (by-nc 3.0) which permits any noncommercial use, distribution, and reproduction in any medium, provided the original author(s) and source are credited. tory (Forshaw, 2000). Migratory birds are most often responsible for the distribution of avian diseases over long distances. Birds serve as hosts for most parasites, including: helminths (Noble \& Noble, 1973; Bush \& Holmes, 1985; Foster et al., 2002; Spassky, 2002; Calvette et al., 2003; Spassky, 2003; Ashenafi \& Eshetu, 2004), ectoparasites (Ehrlich et al., 1988; De Lope \& Moller, 1993; Hill, 1994; Schmäschke et al., 2003; Prelezov \& Koinarski, 2006), protozoa (Noble \& Noble, 1973; Deviche $e t$ al., 2001; Sheridan et al., 2002), and microorganisms that cause a variety of diseases such as avian malaria (Noble \& Noble, 1973), fowl pox (Tarello, 2004), aspergillosis, tuberculosis, avian influenza (Ehrlich et al., 1988), ornithosis, avian influenza (BirdLife, 2006b; WHO, 2005; GROG, 2006). Parasites of animals are not only harmful to themselves, but man is most often the main victim. In the literature, works related to parasites of swallows in Cameroon are rare or completely absent.

This study was undertaken to highlight ectoparasites of swallows. By enabling the veterinary monitoring of swallows, this study might contribute to ecological monitoring programs of swallows with a high potential for migration and spread of disease (Ellioh, 1968; BirdLife, 2006a) resulting in migratory birds becoming a public health problem (Kougoum, 2006). To contribute to the study of parasites of swallows in the Western Highlands of Cameroon, our work was aimed at assessing the prevalence of infestation of swallows by ectoparasites in Dschang and, more specifically, at making an inventory describing parasitic associations, highlighting the influence of sex, weight and the capture site on their prevalence, and in identifying parasites posing a risk to human and animal health.

\section{Materials and methods}

This study was conducted from January 2007 to July 2008 in Dschang, chief town of Menoua Division, West Cameroon. Analyses and observations were made at the Laboratory for Biology and Applied Ecology (LABEA) of the Department of Animal Biology, Faculty of Science at the University of Dschang. Dschang has the following geological coordinates: $5^{\circ} 20^{\prime}-7^{\circ} 00^{\prime} \mathrm{N}$ latitude and $10^{\circ} 30^{\prime}-12^{\circ} 00^{\prime} \mathrm{E}$ longitude, with an average altitude of $1500 \mathrm{~m}$. The annual average temperature is $20.1^{\circ} \mathrm{C}$ and the total rainfall is $1911 \mathrm{~mm}$ (Office of Tourism, 2006). The city is built on the southern slopes of Mount Bamboutos, and has 80,000 inhabitants. Dschang has a rainy climate with a short dry season from mid-November to mid-March. The vegetation is made up of grassland, anthropogenic savannah and mountain forests. Birds were captured in three sites: Site 1 (Campus A of the University of Dschang), Site 2 (Mingmeto) and Site 3 (Tchouale).

\section{Animal material}

Fifty-one (51) swallows were captured in the study area using glue traps placed at the entrance of the nest during the day, and birds were 
captured at dusk (18:30) after the nest was located. After being transported to the laboratory, the swallows were kept alive in cages; those arriving dead were kept in the freezer for a maximum of $12 \mathrm{~h}$. These swallows were examined after collection parameters of the host and habitat such as color, size, weight, and sex. A tank sample was required for this operation. Cotton soaked in chloroform was placed in the tank, the bird was introduced, and the vessel was then closed. Ten minutes later, the bird was removed and its feathers were examined to recover ectoparasites (Clayton \& Wather, 1997). After harvesting, these ectoparasites were directly fixed in a 70\% ethanol solution and identified according to the methods described by Schmäschke et al. (2003). Hoyer's mounting medium was used to clear large specimens, while small specimens were mounted directly between slides and coverslips and examined under a microscope. A micrometer was used to measure the different dimensions of the organs and body, and the whole insect was photographed using a digital camera.

\section{Identification}

Specimens were identified using a key based on ectoparasite morphological criteria and photos of previously described species (Noble \& Noble, 1973; Soulsby, 1982; Schmäschke et al., 2003; Prelezov \& Koinorski, 2006; Taylor et al., 2007).

\section{Parameters measured}

To characterize the parasite communities in the study area, the Shannon index was used to determine diversity. This was calculated using the formula:

where:

$$
H^{\prime}=-\Sigma p_{i} \log _{2} p_{i}
$$

$\mathrm{H}^{\prime}$ varies from 0 to $\log \mathrm{S}$ where $\mathrm{S}=$ number of species;

$\mathrm{p}_{\mathrm{i}}=\mathrm{n}_{\mathrm{i}} / \mathrm{N}, \mathrm{n}_{\mathrm{i}}=$ the population size of species $i$;

$\mathrm{N}=$ total number of species;

$\mathrm{p}_{\mathrm{i}}=$ proportion of species $i$ with respect to the total catch.

The equitability is a parameter to measure the equilibrium level of the population. It is calculated using the following formula:

where

$$
\mathrm{E}=\mathrm{H}^{\prime} / \log _{2} \mathrm{~S}
$$

E ranges from 0 to 1 .

Prevalence (also called extensity or percentage of infestation): The prevalence (usually expressed as a percentage) is the ratio of the number of infected individuals to the total number of individuals sampled.

Statistical analysis: Comparison of prevalence was performed using a Chi-Square test at 5\% significance level; $R$ software, version 2.7.0 was used for data analysis (R Development Core Team, 2008).

\section{Results}

From a total of 51 swallows analyzed, 18 were parasitized by at least one species of ectoparasite, giving an overall prevalence of $35.29 \%$. Four species of ectoparasites were identified.

\section{Eomenacanthus stramineus}

This louse with a yellowish body was especially found in the feathers. The adult parasite has a length of about $2.8 \mathrm{~mm}$ for males and 3.3 $\mathrm{mm}$ for females. The width is 0.8 to $1 \mathrm{~mm}$ and very small antennae, measuring $62.5 \mathrm{~m}$. Each abdominal segment has two thrusts of silk. It was the most prevalent species in this study (Figure 1).

\section{Menacanthus cornutus}

Yellow to reddish, this louse was harvested from the feathers. It is
$2.2 \mathrm{~mm}$ long and $0.90 \mathrm{~mm}$ wide. The abdomen has approximately 8 segments and there is little silk on the body. It has very short antennae, measuring $58 \mathrm{~m}$. This species is easily recognizable by the shape of its abdomen and its relatively small size compared with $E$. stramineus. Its prevalence was $3.92 \%$ (Figure 2).

\section{Goniocotes gallinae}

This louse was collected in the down of the birds. It resembles $E$. stramineus with a broad head and body. Its size is smaller: $3 \times 2.6 \mathrm{~mm}$. The abdomen has nine segments and the body has many dense silks (Figure 3).

\section{Menopon gallinae}

This louse species, which had the same prevalence as $M$. cornutus (3.92\%), was harvested from the feathers. It measures $2.4 \mathrm{~mm}$ long and $0.8 \mathrm{~mm}$ in width; the abdomen comprises 9 segments with numerous large silks. This species is thinner than the others. Its color ranges from white to yellowish (Figure 4).

Swallows captured in this study lived as either couples (Sites 1 and 2 ), or in a colony (Site 3), hence the need to assess the prevalence depending on the site of capture, as shown in Figure 5.

The frequency of $E$. stramineus was relatively higher at Site 3 $(23.52 \%)$ and we observed a significant difference $(\mathrm{P}<0.05)$ from its

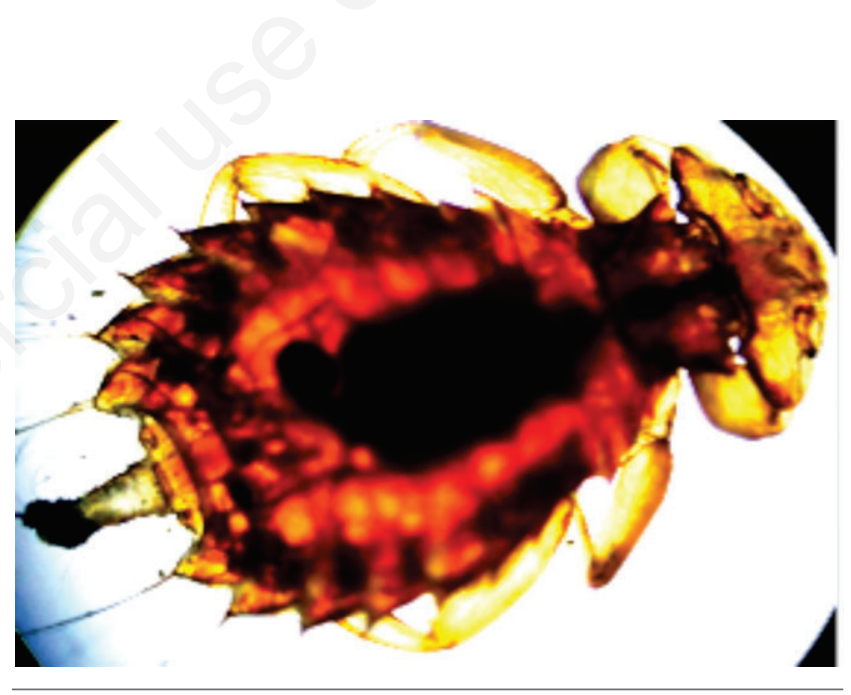

Figure 1. Eomenacanthus stramineus.

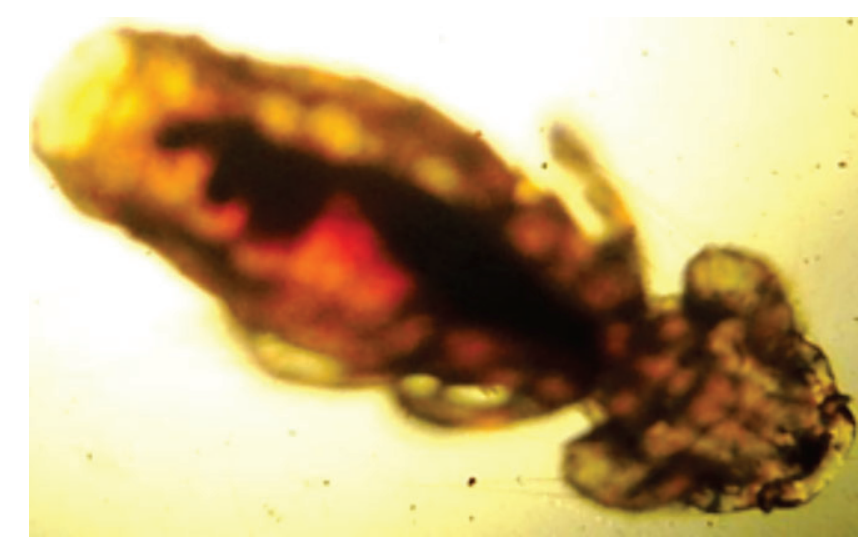

Figure 2. Menacanthus cornutus. 
prevalence in the other two sites (3.92\%). M. cornutus had the same prevalence in Sites 1 and 3 (1.96\%) and was absent in Site 2. There was no significant difference $(\mathrm{P} \geq 0.05)$ among the prevalence of the three sites.

G. gallinae was completely absent in Sites 2 and 3 . It was only found in Site 1 with a frequency of $5.88 \%$. M. gallinae was absent in sites 2 and 3 like $G$. gallinae. It was present at Site 1 with a frequency of $3.92 \%$, with a significant difference $(\mathrm{P}<0.05)$ from the frequency in the 2 other sites. Generally, the four species were present in Site 1, for a total prevalence of $15.69 \%$. Site 2 is represented by a single parasite $E$. stramineus, while Site 3 had two parasites. E. stramineus is the only parasite present in the three sites. The host population consisted of male and female swallows; activities may vary in the two sexes, so we found it necessary to compare the prevalence between the two sexes (Figure 6).

E. stramineus has the same prevalence for both sexes (15.69\%). There was no significant difference $(\mathrm{P} \geq 0.05)$ between the prevalence of $M$. cornutus and $G$. gallinae in both sexes. The only significant difference according to sex was observed in $M$. gallinae, which infested only females with a prevalence of $3.92 \%$. Weight varies, as does size,

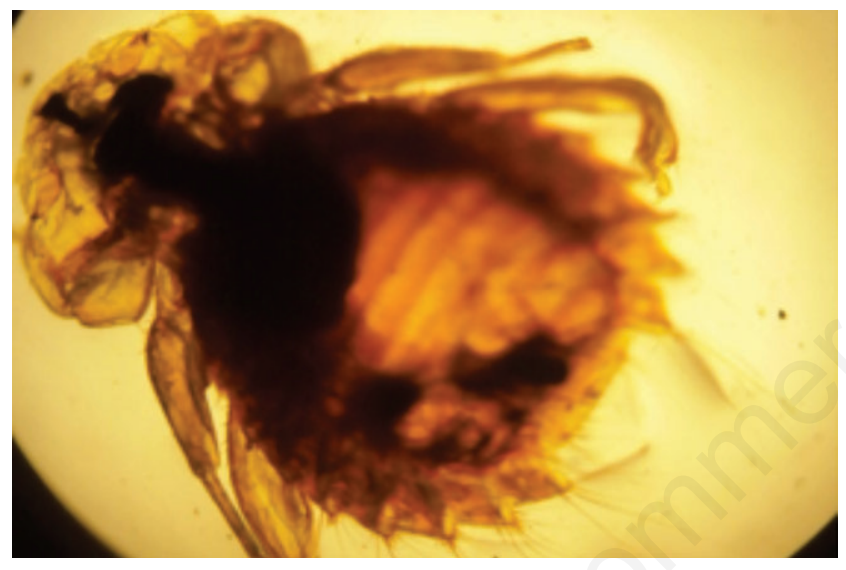

Figure 3. Goniocotes gallinae.

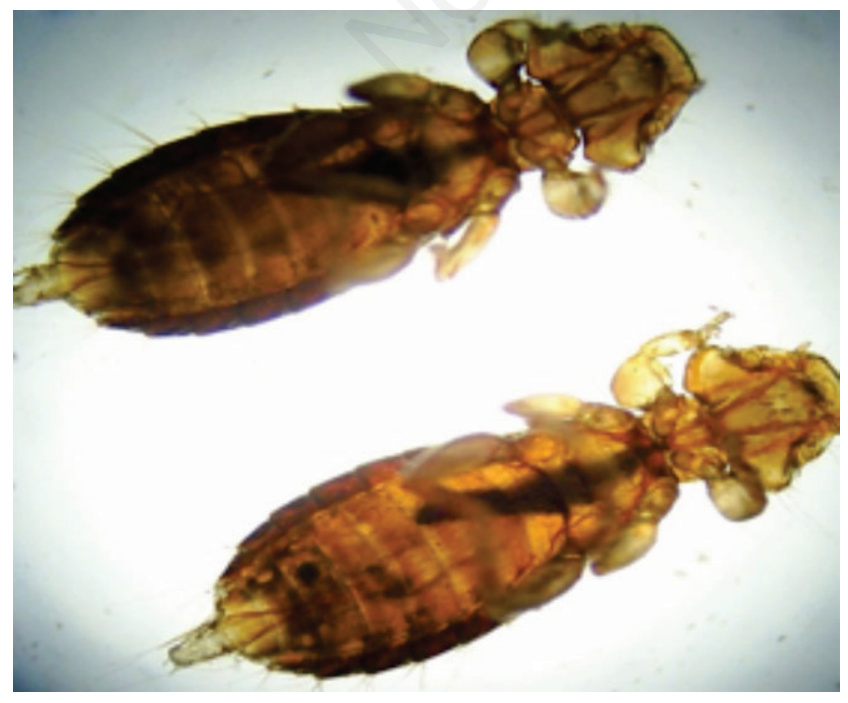

Figure 4. Menopon gallinae. depending on the age and increase in age of the swallows (Figure 7).

No parasites of any species occurred in the 31-40 g weight class. There was no significant difference $(\mathrm{P} \geq 0.05)$ in prevalence between the 11-20 $\mathrm{g}(17.65 \%)$ and $21-30 \mathrm{~g}(11.76 \%)$ weight classes for the parasite $E$. stramineus. For $M$. cornutus, there was no significant difference $(\mathrm{P} \geq 0.05)$ between prevalence in the $11-20 \mathrm{~g}(1.92 \%)$ and $21-30 \mathrm{~g}$ (3.92\%) classes. G. gallinae presented the same distribution as $M$. cornutus, having the same difference between the 11-20 $\mathrm{g}(2 \%)$ and 21-30 $\mathrm{g}(3.92 \%)$ weight classes. $M$. gallinae was present only in the $11-20 \mathrm{~g}$ weight class $(3.92 \%)$, which was significantly different $(\mathrm{P}<0.05)$ from the 21-30 g weight class.

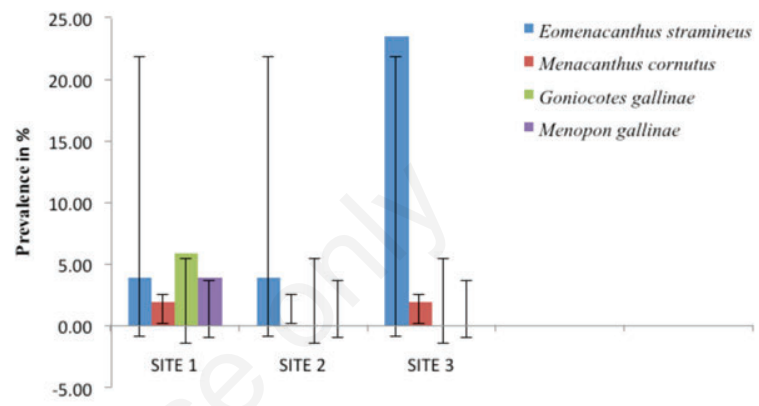

Figure 5. Prevalence in terms of sites.

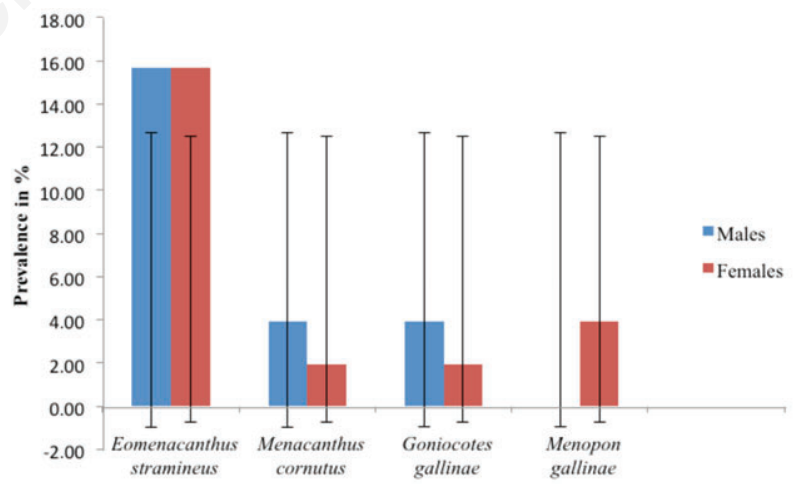

Figure 6. Prevalence of ectoparasites in relation to sex.

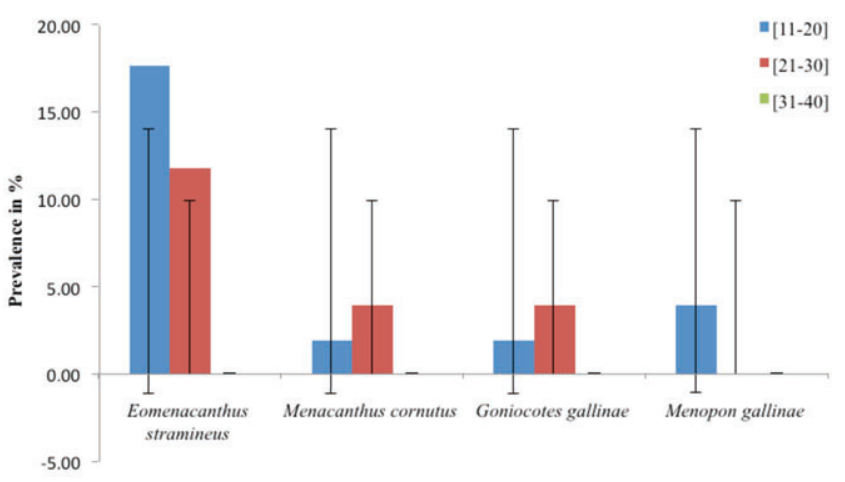

Figure 7. Prevalence of ectoparasites in relation to weight classes. 
The prevalence of mono-parasitic infestation was $28 \%, 4 \%$ for double infestation and $4 \%$ for triple infestation. The diversity index was 1.05 , while the equitability was 0.53 (Table 1 ).

\section{Discussion}

The overall prevalence of ectoparasites of the barn swallow in Dschang was $35.29 \%$. This frequency is relatively higher in comparison with the results from other birds in a study carried out by Schmäschke et al. (2003). They found $11.40 \%$ as the prevalence of ectoparasites of birds representing a large range of species, which implies different lifestyles (single, couples, colonies, migratory and sedentary). Our prevalence is lower in relation to the work of Prelezov \& Koinarski (2006) on poultry in Belgium, probably due to their higher number of specimens and stable climatic conditions in their area of study. They found $M$. gallinae as the species with the highest prevalence (35.9\%) and $M$. cornutus poorly represented (15\%). In our study, M. gallinae and $M$. cornutus were poorly represented (1.92\%), and the most prevalent species was E. stramineus (31.37\%). Nevertheless, they also found the four species described in this study.

These results showed the low diversity of ectoparasites in the area and the four species described are fairly cosmopolitan (Prelezov \& Koinarski, 2006). Kougoum (2006) reported Ornithonyssu sp. in the weaverbird in Dschang, which was not found in swallows. The relatively high frequency of ectoparasites was linked to the social life of swallows that favors the easy transmission of ectoparasites from one bird to another. It is probably for this reason that the sites where the birds live in pairs (Sites 1 and 2) have a relatively low prevalence of ectoparasites as compared with the site where the swallows lived with more than twenty in a nest (Site 3).

Ehrlich et al. (1988) realized that the mortality due to ectoparasites in a colony increased when the number of individuals of the colony was large. These ectoparasites can prevent reproduction in swallows (De Lope \& Moller, 1993), since reproduction is disrupted by environmental contamination (Custer et al., 1998).

Between sites, differences in prevalence were not significant; this could be expected since the three sites are not geographically very isolated from each other. A significant difference was observed between Site 3 compared with Sites 1 and 2 (E. stramineus) and between Site 1 compared with Sites 2 and 3 ( $G$. gallinae and $M$. gallinae). Indeed, the number of hosts is not constant in the three sites and, in terms of climate; there is no demarcation among the three sites.

Taking into account sexes, we did not find any significant difference between the prevalence in males and females for $E$. stramineus, $M$. cornutus and $G$. gallinae, probably due to lifestyle characteristics for a mating pair that assumes the two sexes are exposed to the same risks. Only M. gallinae was found only in females, at a $3.92 \%$ frequency. In the literature, works describing a difference in prevalence between males and females for ectoparasites of birds are rare.

Lighter weight swallows (11-20 g) showed a relatively high parasitic

Table 1. Results of the survey.

\begin{tabular}{lcc} 
& Yes & No \\
& $(\%)$ & $(\%)$ \\
Are you passionate with swallows? & 65 & 35 \\
Do you eat swallows? & 30 & 70 \\
\hline Have you witnessed swallow consumption? & 15 & 85 \\
Are swallows used in medicines in your tradition? & 55 & 4 \\
\hline
\end{tabular}

infestation of $E$. stramineus. For the other parasites, there was no significant difference between the prevalence in different weight classes (11-20 $\mathrm{g}$ and 21-30 g). At the same time, the 31-40 g weight class was not infested, and it was in this weight class that only adult birds were found and were also poorly represented in this study. The class with the highest prevalence of ectoparasites (11-20 g) contained many young birds, which not only have weak immune systems, but also are highly represented in terms of numbers.

Cases of parasitic association of $E$. stramineus $+G$. gallinae and $E$. stramineus $+M$. cornutus were found. This is due to the fact that these species exploit different resources of the host, and thus belong to different guilds and therefore evolve neutrally. Although $E$. stramineus was involved in parasitic associations, simple infestations by this parasite were very common; this is due to the fact that this parasite can infect a single host in large numbers, often more than 6000 individuals (Noble \& Noble, 1973).

The results of our surveys showed that the swallows are consumed and used in traditional medicine. This implies that users can deal with the risks. The constitution of swallows' nests (mud, grass, twigs, feathers, silk) shows that they explore many media for nest building from water to scrub to soil matter, which is a factor in exposure to parasites and interactions with other animals. Adeyemo et al. in 2006 showed a convergence of several animals, including birds, going to water several times a day. The diversity index was not maximal, so some species were more represented and more abundant ( $E$. stramineus). The equitability measure is an index that ranges from 0 (one species dominates) to 1 (species are present in the same number). The values obtained showed that the species found are more or less evenly distributed, as our values were halfway between the minimum and the maximum.

\section{Conclusions}

Barn swallows in Dschang harbor several species of ectoparasites. Among these parasites, the species $E$. stramineus was the most prevalent. We found four species of ectoparasites. Sex of the host did not have a significant influence on the frequency of ectoparasites, nor did sample site for the majority of parasites. Because swallows nest on human settlements and harbor parasites, they may pose a risk to human health and impact the swallows' behavior. This potential makes migratory birds a public health problem (Kougoum, 2006), as its relationship to avian influenza could also pertain to other avian diseases, although we have not found any zoonotic species. The diversity of building materials used in swallow nests indicated their exploration of different media for nest building and therefore the potential for exposure to ectoparasites. Given the results obtained and the constraints encountered, we consider that attention should be given to the following: a larger sample size to reduce potential bias; a capture period during all months of the year to more accurately characterize captures, which should involve a large team because the operation is relatively difficult; the use of telemetry to monitor and determine migration routes from Europe to Africa for migratory swallows, to assess their ability to distribute parasites, if necessary; a study of blood parasites, microorganisms and viruses, and the study of the influence of the types of nests on the frequency of ectoparasites.

\section{References}

ADEYEMO A.I., TAMUNGANG A., AYODELE I.A., 2006 - Convergence of Wild Animals at river Oli Banks in Kainji Lake National Park, Nigeria. - Res. J. Biol. Sci. 1: 98-101. 
ASHENAFI L.H., ESHETU Y., 2004 - Enquête sur les helminthes gastrointestinaux des poulets du centre Ethiopie. - Rev. Med. Vet. 10: 504-507.

BIRDLIFE, 2006a - Birdlife international's review of the status of the African grey parrot and proposals to CITES for its conservation. $22^{\text {nd }}$ Meet. Animals Committee. - Available from: http://www. birdlife.org

BIRDLIFE, 2006b. - Wild birds and avian influenza. - Available from: http://www.birdlife.org/action/science/species/avian-flu/birds-faghtml Accessed: 28 July 2007.

BUSH A.0., HOLMES I.C., 1986 - Intestinal Helminths of lesser scaup ducks: an interactive community. - Can. J. Zool. 64: 142-152.

CALVETTE C., BLANCO-AGUIAR J.A., VIRG ST E., CABEZAS-D AS S., VILLAFUERTE R., 2003 - Spatial variation in helminth community structure in the red-legged partridge (Alectoris rufa L.): effects of definitive host density. - Instituto de Investigaci n en Recursos Cinegéticos (IREC, CSIC-UCLM-JCCM), E-13080 Ciudad Real.

CLAYTON D.H., WALTHER B.A., 1997 - Collection and quantification of Arthropod parasites of birds. In: CLAYTON D.H. and MOORE J. (ed), Host-parasite co-evolution. General principles and avian models. - Oxford University Press, Oxford: 419-440.

CUSTER C.M., CUSTER T.M., ALLEN P.D., STROMBORG K.L., MELANCON M.J., 1998 - Reproduction and environmental contamination in tree swallow nesting in the Fox River drainage and Green Bay. Environ. Toxicol. Chem. 17: 1786-1798.

DE LOPE F., MOLLER A.P., 1993 - Effects of ectoparasites on reproduction of their swallow hosts: a cost of being multi-brooded. - Oikos. 67: 557-562.

DEVICHE P., GREINER E.C., MANTECA X., 2001 - Interspecific variability of prevalence in blood parasites of adult passerine birds during the breeding season in Alaska. - J. Wildlife Dis. 7: 28-35.

EHRLICH P., DOBKIN D., WHEYE D., 1988 - The birders handbook: a field guide to the natural history of North American birds. - Simon and Schuster Inc., New York, NY.

ELLIOH A.M., 1968 - Zoology. IV ed. - Meredith Corporation, New York, NY: 779.

FORSHAW J.M., 2000 - The little guide, birds. - Fog City Press, San Francisco: 320 .

FOSTER G.W., KINSELLA J.M., WATERS E.L., SCHRADER M.S., FORESTER D.J., 2002 - Parasitic Helminths of red-belled wood- peckers (Melanerpes carolinus) from the Apalachicola National Forest in Florida. J. Parasitol. 88: 1140-1142.

GR0G, 2006 - Grippe aviaire. Available from: http://www.grog.org/grippeaviaire.html Accessed: 02 August 2006.

HILL J.R, 1994 - An introduction to the ectoparasites of purple martins. Purple Martin Conservation Association. - Purple Martin Update 5: 1-7.

KOUGOUM P.G., 2006 - Prévalences parasitaires, bactériennes et fongiques chez le tisserin villageois (Ploceus cucullatus) dans la ville de Dschang et ses environs. Thèse de Master. Faculté des sciences. - Université de Dschang: 98.

NOBLE E.R., NOBLE G.A., 1973 - Parasitology: the biology of animal parasites. III ed. -Lea and Fibiger, Philadelphia: 617.

OFFICE OF TOURISM, 2006 - Plan et guide touristique de la ville de Dschang. - Association Pays de la Loire/Cameroun, Office du Tourisme, Dschang.

PRELEZOV P.N., KOINARSKI V.T.S., 2006 - Species variety and population structure of Mallophaga (Insecta: Phthiraptera) on chickens in the region of Stara Zagora. - Bulg. J. Vet. Med. 9: 193-200.

R DEVELOPMENT CORE TEAM. 2008. R: A language and environment for statistical computing. - R Foundation for Statistical Computing, Vienna. Available from: http:/www.R-project.org

SCHMÄSCHKE R., SCHSE M., EULENBERGER K., SCHÖN R. 2003 Quill mites - little known parasites of birds. - Vesh. Er. Erkrg. Zootière. 41: 127-133.

SHERIDAN K.L., KENNETH S., 2002 - An overview of atoxoplasmosis in birds. - College of Veterinary Medicine, Athens.

SOULSBY E.J.L., 1982 - Helminthes, Arthropods, Protozoa of domesticated animals. 7th ed. - Baillie Tindal, London: 809.

SPASSKY A.A., 2002 - Neoliginae, subfamily N (Syn.Tr. Neoligini Spassky, 1980), a new subfamily of Cyclophyllidean Cestodes. - Acta Zool. Lituan. 12: 86-89.

SPASSKY A.A., 2003 - Arostellininae, Subfam. N., Anew subfamily of Dilepidid cestodes. - Acta Zool. Lituan. 13: 327-329.

TARELLO W., 2004 - La variole aviaire chez les psittacidés en Arabie Saoudite. - Rev. Méd. Vét. 10: 483-485.

TAYLOR M.A., COOP R.L., WALL R.L., 2007. Veterinary parasitology. III ed. - Blackwell Publishing, Oxford: 799-847.

WHO, 2005 - H5N1 avian influenza. Available from: http://www.who. int/avianinfluenza Accessed: 18 April 2006. 